\title{
The Year 2012 in International Criminal Courts and Tribunals: A Retrospect
}

\author{
Henri Decour*
}

2012 was a vintage year for international criminal law. After ten years in existence, the International Criminal Court (ICC) rendered the first two judgments of its history, as well as a decision spelling out the principles governing reparations to victims. Former President of Liberia Charles Taylor was convicted by the Special Court for Sierra Leone (SCSL), marking the first time a former head of state was convicted by an international tribunal since Nuremberg. ${ }^{1}$ Judgments delivered by the International Criminal Tribunal for the former Yugoslavia (ICTY), now on the verge of reaching the end of its mandate, gave rise to fierce controversy. The legitimacy of the Special Tribunal for Lebanon (STL) was-unsuccessfully-challenged. Not to be outdone, the Extraordinary Chambers in the Courts of Cambodia (ECCC) concluded their first cases against former members of the Khmer Rouge regime.

These important decisions have already been, or will undoubtedly be, abundantly commented upon. ${ }^{2}$ Rather than superficially touching upon what others have analysed, or will analyse in extensive depth, this short note selectively focuses on specific issues. It identifies and comments on dominant themes in the past year's decisions-threads running through the case law which, by their nature, reflect the controversies, orientations, and evolutions that have nourished the field since its earliest developments. This note will accordingly discuss three main points. The first is partly political in nature: it concerns the diverse forms of criticism and challenges that international criminal tribunals faced in 2012. The second is more substantive: it considers how the concept of reasonable doubt

PhD Candidate, University of Cambridge.

1 Karl Dönitz, who became the German Head of State on 1 May 1945 after Adolf Hitler's suicide, was sentenced to ten years of imprisonment by the International Military Tribunal.

2 See e.g. on the Lubanga judgment, K Ambos, 'The First Judgment of the International Criminal Court (Prosecutor v Lubanga): A Comprehensive Analysis of the Legal Issues' (2012) 12 ICLR 115; T R Liefländer, 'The Lubanga Judgment of the ICC: More than Just the First Step?' (2012) 1 CJICL 191.

Copyright $\odot$ the Author(s).

This work is licensed under a Creative Commons Attribution-NonCommercial-NoDerivs 3.0 License. 
was applied by judges. The third is a matter of normative discourse: it considers the extent to which international human rights law was used as a yardstick for reviewing and developing norms in international criminal proceedings.

\section{Challenges to the legitimacy of international criminal jurisdictions}

In 2012, international criminal courts and tribunals were not spared controversies, either legal or political. Criticism was voiced not only by outsiders, but also by actors involved in cases, to question the legality of these institutions' existence, the rigour of their legal reasoning as well as their prosecutorial policy.

\subsection{Challenges to the legality and jurisdiction of the STL}

On 27 July 2012, the STL rendered its Decision on the Defence Challenges to the Jurisdiction and Legality of the Tribunal. ${ }^{3}$ The defence sought to challenge the legality of the STL's creation, arguing inter alia that the UN Security Council acted ultra vires in establishing the Tribunal and violated the sovereignty of Lebanon by imposing a draft agreement which had not been ratified by the Lebanese Parliament. Not surprisingly, the STL, carefully sticking to the precedent established by the ICTY Appeals Chamber's decision on jurisdiction in Tadic, ${ }^{4}$ rejected the defence motions. Being 'purely a creature of a Security Council Resolution, ${ }^{5}$ it declined to review the legality of the action of the Security Council. ${ }^{6}$

\subsection{Controversies and judicial shortcomings at the ICTY}

A series of ICTY judgments in late 2012 provoked an unusually vehement backlash. On 16 November, the ICTY Appeals Chamber overturned the convictions entered against Croatian generals Ante Gotovina and Mladen Markač for their alleged role in Operation Storm in 1995. ${ }^{7}$ Scenes of jubilation were reported in

\footnotetext{
3 Prosecutor $v$ Salim Jamil Ayyash et al, Decision on the Defence Challenges to the Jurisdiction and Legality of the Tribunal, Case No STL-11-01, 2012.

4 See Prosecutor $v$ Duško Tadić, Decision on the Defence Motion for Interlocutory Appeal on Jurisdiction, Case No IT-94-1, 1995.

5 Ayyash et al, above n 3, para 53.

6 Ibid, in particular paras 55 and 71.

7 Prosecutor v Ante Gotovina and Mladen Markač, Appeals Judgment, Case No IT-06-90, 2012.
} 
Zagreb, where Ante Gotovina was welcomed by thousands of people. Serbia, for its part, denounced the judges' decision, accusing the Tribunal of 'open[ing] old wounds' ${ }^{8}$ and showing political bias in its approach to the conflict in the former Yugoslavia. A few days later, a trial chamber delivered its judgment in the retrial of Ramush Haradinaj, Idriz Balaj, and Lahi Brahimaj for crimes allegedly committed, inter alia, against Serbs in Kosovo, ${ }^{9}$ acquitting the defendants on all counts and thereby fuelling perceptions of bias in Serbia. As the judges of the STL put it, "selectivity" is part of the history of international criminal jurisdictions, and an inevitable consequence of establishing an international criminal court or tribunal.'10

Beyond political controversies, the legal reasoning of the ICTY Appeals Chamber in Gotovina and Markač attracted much criticism. Two of the five judges on the bench indeed expressed their dissent in the most radical terms. At the core of the dissent was the way in which the majority of the Appeals Chamber reviewed the Trial Chamber's analysis of the lawfulness of artillery attacks. To cut a long story short, the Trial Chamber had ruled that all impacts situated within 200 metres of an identified military objective were to be deemed lawful, while all those falling beyond had to be considered indiscriminate and hence unlawful. This arbitrary standard was unanimously rejected by the Appeals Chamber. All judges agreed that no evidence on the record, including testimonies of several artillery experts, could reasonably lead to the conclusion that 200 metres was an appropriate estimate. ${ }^{11}$ Consensus, however, ended here. Unfortunately, the majority did not define the appropriate standard for assessing the lawfulness of the attacks, thus failing to apply the norm of review enunciated at the beginning of the judgment: 'Where the Appeals Chamber finds an error of law in the trial judgment arising from the application of an incorrect legal standard, the Appeals Chamber will articulate the correct legal standard and review the relevant factual findings of the trial chamber accordingly. ${ }^{, 12}$ The majority thus simply dismissed the Trial Chamber's analysis and failed to review de novo the evidence, taking questionable analytical shortcuts to make the entire trial judgment fall apart like a house of cards. ${ }^{13}$ Regrettably, by attributing a disproportionate significance to

${ }_{8}^{8}$ J Borger, 'War Crimes Convictions of Two Croatian Generals Overturned', The Guardian, 16 November 2012, <http://www.guardian.co.uk/world/2012/nov/16/war-crimes-convictionscroat-generals-overturned $>$ [accessed 2 March 2012].

9 Prosecutor v Haradinaj et al, Retrial Judgment, Case No IT-04-84, 2012.

${ }^{10}$ Ayyash et al, above n 3, para 87.

${ }^{11}$ See the discussion of the Trial Chamber's analysis in Gotovina and Markač, above n 7, paras 52-61.

${ }^{12}$ Ibid, para 12.

${ }^{13}$ See Prosecutor v Ante Gotovina and Mladen Markač, Dissenting Opinion of Judge Carmel Agius, 
the question of the 200 metres standard, the Appeals Chamber did not address in sufficient detail equally important issues. Ante Gotovina and Mladen Markač spent years in detention and suffered the stigma of being labelled war criminals, eventually to be found not guilty. They deserved, at the very least, a more rigorous judgment. So did the victims of the crimes committed by the Croatian Army during Operation Storm.

\subsection{Criticism of prosecutorial policy}

Another notable development of the year was the ICC Trial Chamber's critique of the way in which the Prosecutor handled the Ngudjolo case. The judges unanimously acquitted Mathieu Ngudjolo Chui, who had been charged with war crimes and crimes against humanity as indirect co-perpetrator for his alleged role in the attack on the village of Bogoro in the Ituri Province of the Democratic Republic of Congo in February 2003. Whilst the Trial Chamber found that crimes such as murder, plunder, and rape had undoubtedly been committed against civilians during the attack (including by child soldiers), it was not in a position to determine the role played by the accused at the time. ${ }^{14}$

The Trial Chamber did not sanction the Prosecutor for having changed his argument regarding the position of the accused in different armed groups, since the modification did not alter, in substance, the charges as confirmed by the Pre-Trial Chamber. ${ }^{15}$ The judgment, however, contains a section specifically dedicated to listing the shortcomings of the investigation conducted by the Office of the Prosecutor. Although the Trial Chamber acknowledged the difficulty of investigating this case, it blamed the Prosecutor for having failed to call potentially important witnesses and to analyse certain points in sufficient depth. ${ }^{16}$ What is more, contradictions, lies, and suspicious behaviour marred the testimony of many witnesses and cast significant doubts on their credibility. As a result, the testimony of several key witnesses in the Prosecutor's case was entirely dismissed by the Trial Chamber.

This judgment sheds light on the challenges faced by the Office of the Prosecutor in investigating and prosecuting wartime atrocities. It is difficult to

paras 3-4.

${ }^{14}$ Prosecutor v Mathieu Ngudjolo Chui, Trial Judgment, Case No ICC-01/04-02/12, 2012. One may regret that the Trial Chamber did not express its view on the law applicable to indirect co-perpetration and on the import of German criminal law doctrine, as Judge van den Wyngaert did in her Separate Opinion.

15 Ibid, paras 350-1.

${ }^{16}$ Ibid, paras $115-23$. 
assess how it will reflect on the Court's image and whether it will improve its legitimacy. If the Prosecutor is deemed incapable of building a strong case against one middle-ranking accused for a very narrow set of facts, how can he/she be expected to deal with large-scale cases involving high-level political and military leaders?

The question of prosecutorial discretion was addressed by the ECCC Supreme Court Chamber in the case against Duch, former director of the Khmer Rouge S-21 security centre. ${ }^{17}$ Responding to the appellant's argument that the ECCC lacked jurisdiction to try him because he was not one of the 'senior leaders of Democratic Kampuchea and those who were most responsible', the Supreme Court Chamber rejected the argument as being essentially a matter of prosecutorial policy. Interestingly, however, referring to precedents, the judges ruled that they had 'the power to review the discretion of the Co-Investigating Judges and the Co-Prosecutors on the ground that they allegedly exercised their discretion [...] in bad faith or according to unsound professional judgment. ${ }^{18}$ That being said, this power of review remains 'extremely narrow in scope.19

\section{Reasonable doubt as an instrument of judicial reasoning}

An interesting feature of recent cases is the recurrent emphasis on the standard of reasonable doubt, with the purpose of either exculpating the accused or distinguishing between different forms of liability.

\subsection{Doubts exculpating the accused}

As pointed out above, the acquittal of Mathieu Ngudjolo was due to a lack of evidence. The Ngudjolo judgment is entirely built around the notion of reasonable doubt. As the judges rightly recalled, the fact that an allegation is not

${ }_{17}$ Kaing Guek Eav alias Duch, Appeal Judgment, Case No 001/18-07-2007/ECCC, 2012. In this case, the Supreme Court Chamber continued the ECCC's delicate task of ascertaining the contours of customary law in the time before the creation of the ad hoc tribunals (see Khieu Samphan et al, Decision on the Appeals against the Co-Investigative Judges Order on Joint Criminal Enterprise, Case No 002/19-09-2007-ECCC, 2010, paras 53-88). The Supreme Court Chamber thus held that in 1975-1979 rape did not constitute a crime against humanity under customary international law (see paras 168-213).

18 Ibid, para 80.

19 Ibid. 
proven beyond reasonable doubt does not necessarily imply that the allegation is unfounded. It only means that the available evidence was not sufficient, or not reliable enough, to verify its truthfulness. As a result, a verdict declaring the accused not guilty does not necessarily mean that the accused is innocent. It merely means that the evidence presented at trial was insufficient to convince the Court beyond any reasonable doubt. ${ }^{20}$

In the view of the Trial Chamber, the evidence on the record established that the accused enjoyed a rising social status owing to his recognised military expertise and that he had become a key local actor in the time following the attack of Bogoro. However, the Trial Chamber could not determine precisely what role, if any, Mathieu Ngudjolo played in the attack. Although the Trial Chamber could not rule out the possibility that the accused might indeed have had authority over the armed militia responsible for the attack, in the absence of reliable information it was not convinced beyond a reasonable doubt that this was the case. ${ }^{21}$ The Trial Chamber sent a strong message: it recalled that international criminal trials are, if not only, at least primarily about judging the responsibility of a person.

The concept of reasonable doubt was also central to Judge Nyambe's dissent in Tolimir. On 12 December 2012, the ICTY found Zdravko Tolimir, former Assistant Commander for Intelligence and Security of the Bosnian Serb Army, guilty of genocide and sentenced him to life imprisonment for his participation in a joint criminal enterprise (JCE) to murder the able-bodied Bosnian Muslim men from the enclave of Srebrenica. ${ }^{22}$ In her dissenting opinion, Judge Nyambe insisted on the 'benefit of the doubt' to systematically reject evidence she believed did not meet the required threshold of persuasiveness. ${ }^{23}$

\subsection{Doubts drawing the line between modes of responsibility}

Whilst, in the cases presented above, the concept of reasonable doubt was invoked in support of the accused's acquittal, in the SCSL judgment of 18 May 2012 in the case against Charles Taylor, it served the purpose of distinguishing between different forms of liability. The judges first dismissed the Prosecutor's allegation that the accused acted as member of a JCE pursuant to 'a common purpose to terrorize the civilian population of Sierra Leone. ${ }^{24}$ The Trial Chamber concluded

\footnotetext{
${ }^{20}$ Ngudjolo, above n 14, para 36.

${ }^{21}$ Ibid, para 501.

22 Prosecutor v Zdravko Tolimir, Trial Judgment, Case No IT-05-88/2, 2012.

${ }^{23}$ Ibid, Dissenting and Separate Concurring Opinions of Judge Prisca Matimba Nyambe.

${ }^{24}$ Prosecutor $v$ Charles Ghankay Taylor, Trial Judgment, Case No SCSL-03-01, 2012, paras 6895-6.
} 
that 'th[e] evidence clearly shows that the Accused and the RUF [Revolutionary United Front of Sierra Leone] were military allies and trading partners, but it is an insufficient basis to find beyond reasonable doubt that the Accused was part of any JCE. ${ }^{25}$

Then, however, when assessing the responsibility of the accused under other modes of liability, the Trial Chamber found the accused guilty not only of aiding and abetting, but also of planning crimes alleged in the indictment. According to the judges, the accused, together with the leadership of the RUF, 'intentionally designed a plan for the [invasion of Freetown]' which 'substantially contributed to the RUF/AFRC [Armed Forces Revolutionary Council] military attacks' involving the commission of crimes, and intended, or was aware of the substantial likelihood of such crimes being committed. ${ }^{26}$

At first glance, the findings of the SCSL might seem confusing. It is indeed difficult to see where the judges drew the line between the common criminal purpose required for JCE liability, and the act of designing the (potentially) criminal conduct required by responsibility for planning. Even though there is, in abstract legal terms, little difference between these two material elements, the difference, as a matter of fact, is not negligible in this case. The plan for which the accused was found guilty was much narrower in scope than the alleged common criminal purpose. Whilst evidence demonstrated the existence of a plan to invade Freetown, it did not establish beyond reasonable doubt the existence of a common criminal purpose in the form of a generalised campaign of terror aiming at controlling the population and territory of Sierra Leone and pillaging its resources. The concept of reasonable doubt was thus used as a means of delineating the exact responsibility of the accused based on the available evidence.

\section{The influence of international human rights law}

It is striking that recent decisions make abundant references to international human rights law. Human rights instruments as well as the jurisprudence of human rights courts and treaty bodies have been substantially relied upon to evaluate and develop the law applicable to international criminal trials.

\footnotetext{
${ }^{25}$ Ibid, para 6899.

${ }^{26}$ Ibid, paras 6954-71.
} 


\subsection{Normative evaluation of procedural safeguards}

In response to the defence's argument that the tribunal had not been 'established by law', the STL, following Tadić, undertook to assess whether its Statute and Rules of Procedure and Evidence met the standards of international human rights law with respect to fair trial rights. ${ }^{27}$ Yet although the Trial Chamber considered that applicable human rights standards included those laid down by the United Nations Human Rights Committee, the European Court of Human Rights (ECtHR), the Inter-American Court of Human Rights (IACtHR), and the African Court of Human Rights, ${ }^{28}$ in fact it carried out a relatively superficial survey of international human rights law, merely referring to the major international human rights treaties and citing a couple of cases from the ECtHR and the Human Rights Committee. The STL did not really push its analysis further than the ICTY did in Tadić. ${ }^{29}$

\subsection{Detention of the accused and fitness to stand trial}

On 13 September 2012, the ECCC ruled again on Ieng Thirith's fitness to stand trial. $^{30}$ Repeated expert assessments had concluded that Ieng Thirith, former Social Action Minister of Democratic Kampuchea, was suffering from significant cognitive impairments probably caused by Alzheimer's disease, and that no further treatment would be likely to improve her condition. The Trial Chamber, in assessing whether the accused could still validly be kept in detention while unfit to stand trial, applied standards developed by the ECtHR and the IACtHR to conclude that 'the continued detention of an Accused who is unfit to stand trial can only be justified where there is a substantial likelihood that he or she may become fit to stand trial in the foreseeable future (and thus, where there is a reasonable prospect of that individual being tried without undue delay), ${ }^{32}$ The judges ordered the immediate release of Ieng Thirith.

\footnotetext{
${ }^{27}$ Ayyash et al, above n 3, paras 73-88.

${ }^{28}$ Ibid, para 74.

${ }^{29}$ See Tadić, above n 4, paras 45-7.

${ }^{30}$ Ieng Thirith, Decision on Reassessment of Accused's Fitness to Stand Trial Following Supreme Court Chamber Decision of 13 December 2011, Case No 002/19-09-2007/ECCC, 2012.

31 Ibid, para 22.

${ }^{32}$ Ibid, para 23.
} 


\subsection{Victims' participation and reparation}

In Duch, the ECCC Supreme Court Chamber further ruled on the law governing the participation of victims as civil parties. In determining the standard of proof required to grant a civil party application, it embarked on a relatively detailed analysis of reparation proceedings before the ECtHR and the IACtHR, ${ }^{33}$ reaching the conclusion that 'legal precepts of regional human rights mechanisms do not necessarily provide guidance for civil actions in criminal cases.' ${ }^{34}$ In short, the Trial Chamber considered that regional human rights courts 'operate under a different legal framework and are animated by different policies. ${ }^{35}$

The issue of victims' rights in international criminal proceedings was also extensively addressed by the ICC in Lubanga. After its 2008 Decision on Victims' Participation, ${ }^{36}$ on 7 August 2012 the Trial Chamber ruled on the principles applicable to reparations. ${ }^{37}$ In addition to referring to the UN Basic Principles and Guidelines on the Right to a Remedy and Reparation for Victims of Gross Violations of International Human Rights Law and Serious Violations of International Humanitarian Law, ${ }^{38}$ the Court held that 'general concepts relating to reparations which have been established through the jurisprudence of [regional human rights] courts can provide useful guidance to the ICC. ${ }^{39}$ The Court thus relied heavily on international human rights instruments as well as on the jurisprudence of the ECtHR and the IACtHR to determine the principles governing the modalities of reparations, in particular with respect to compensation and the definitions of harm, rehabilitation, and causation. ${ }^{40}$

\section{Conclusion}

The developments of the case law in 2012 analysed here are not in themselves groundbreaking. They are, however, emblematic of what international criminal law is about, and tell us something about its future. Whether expectations for the

\footnotetext{
$\overline{33}$ Duch, above n 17, paras 431-5, 516-19.

${ }^{34}$ Ibid, para 435.

35 Ibid, para 431.

${ }^{36}$ Prosecutor $v$ Thomas Lubanga Dyilo, Decision on Victims' Participation, Case No ICC-01/04-01/06, 2008.

${ }^{37}$ Prosecutor $v$ Thomas Lubanga Dyilo, Decision Establishing the Principles and Procedures to be Applied to Reparations, Case No ICC-01/04-01/06, 2012.

${ }^{38}$ UN General Assembly, UN Doc. A/RES/60/147 (2006).

${ }^{39}$ Lubanga, Decision on Reparations, above n 37, 67 (n 377).

${ }^{40}$ Ibid, paras 229-50.
} 
ICC will be met also depends on the rigour, coherence, and intellectual honesty of the judges' rulings, and on the way in which they incorporate the normative heritage of the discipline. 